\title{
Toxic trace elements in solid airborne particles and ecological risk assessment in the vicinity of local boiler house plants
}

\author{
Anna V. Talovskaya*, Nina A. Osipova, Egor G. Yazikov, Tatyana S. Shakhova \\ Tomsk Polytechnic University, 30 Lenin Avenue, Tomsk, Russia, 634050
}

\begin{abstract}
The article deals with assessment of anthropogenic pollution in vicinity of local boilers using the data on microelement composition of solid airborne particles deposited in snow. The anthropogenic feature of elevated accumulation levels of solid airborne particles deposited in snow in the vicinity of coal-fired boiler house is revealed in elevated concentrations (3-25 higher than background) of $\mathrm{Cd}, \mathrm{Sb}, \mathrm{Mo}, \mathrm{Pb}, \mathrm{Sr}, \mathrm{Ba}, \mathrm{Ni}, \mathrm{Mo}, \mathrm{Zn}$ and $\mathrm{Co}$. In the vicinity oil-fired boiler house the specific elements as parts of solid airborne particles deposited in snow are $\mathrm{V}, \mathrm{Ni}$ and $\mathrm{Sb}$, as their content exceeds the background from 3 to 8 times. It is determined that the maximum shares in non-carcinogenic human health risk from chronic inhalation of trace elements to the human body in the vicinity of coal-fired boiler house belong to $\mathrm{Al}, \mathrm{Mn}, \mathrm{Cu}$, $\mathrm{Ba}, \mathrm{Co}, \mathrm{Pb}$, whereas in the vicinity of oil-fired boiler house - $\mathrm{Al}, \mathrm{Mn}, \mathrm{Cu}, \mathrm{Ni}, \mathrm{V}$.
\end{abstract}

Keywords: boiler-house plant, snow cover, solid airborne particles, trace elements, environment risk assessment

\section{INTRODUCTION}

Particulate matter (PM) is solid or liquid particles suspended in the Earth's atmosphere. Anthropogenic sources of particulate matter are fuel combustion in car engines and fossil fuel combustion by thermal and industrial plants [1-3]. As thermal facilities operating on coal take the first place in the amount of solid particle emissions and those using liquid fuels take the second place, the urgent issue is to study sizes and composition of released particles [4]. Fine and ultra-fine particles formed in fossil fuel combustion can have a negative effect on cardio-vascular system [5].

In winter the amount of burnt fuel achieves its maximum and, as a result of wet and dry deposition, released solid particles settle on the snow cover, which results in certain anthropogenic load in the residential areas located close to thermal facilities and poses a risk for human health. Snow is one of the most informative indicators to assess the air pollution of a site, which has been shown by the authors [6-9] as well as our researchers [10-12]. The relevance of such studies increases if they are added with assessment of ecological-hygienic criteria of toxic properties of the identified elements and/or their compounds [12].

The purpose of this article is to assess the air pollution level in vicinity of coal-fired and oil-fired boiler-house plants in the territory of Tomsk Oblast. The main objectives of the present study are (a) to determine the content of trace elements in solid airborne particles deposited in snow; (b) to reveal the most hazardous elements with the maximum concentrations in solid airborne particles deposited in snow depending on used fuel type in the boiler-house plants; (c) to assess the non-carcinogenic risk of population health from chronic inhalation of trace elements contained in solid airborne particles.

\section{METHODS}

Snow sampling was performed at the end of February, 2016 to study the composition of solid particles deposited in snow cover over the winter season. In the vicinity of coal-fired boiler house the sampling points were located at the distance from 30 to $230 \mathrm{~m}$ from the stack, oil-fired boiler house - from 50 to $250 \mathrm{~m}$ from the stack along the main wind direction. Sampling and snow sample preparation were made in accordance with regulations (RD 52.04.186 № 2932-83), a number of published research works [6-9] and our research experience [10-12].

*talovskaj@yandex.ru; phone +7 96278509 49; fax +7 3822418910 
The object of the study was a solid snow phase in the form of solid airborne particles deposited in snow. Concentration of $\mathrm{Al}, \mathrm{As}, \mathrm{Cd}, \mathrm{Se}, \mathrm{Pb}, \mathrm{Zn}, \mathrm{Co}, \mathrm{Ni}, \mathrm{Mo}, \mathrm{Cu}, \mathrm{Sb}, \mathrm{Cr}, \mathrm{Ba}, \mathrm{V}, \mathrm{Mn}, \mathrm{Sr}$ and $\mathrm{W}$ was defined in 17 samples using massspectrometry with inductively couples plasma (ICP-MS). Hg concentration was measured in the samples by atomicabsorption analysis.

In the present study to reveal the abnormal microelement concentration as compared to background one, the concentration coefficient of trace elements $\left(\mathrm{K}_{\mathrm{k}}\right)$ is determined using the formula [6-7]:

$$
K_{k, i}=C_{i} / C_{f}
$$

$\mathrm{C}_{\mathrm{i}}$ is the trace element concentration in the considered snow sample $(\mathrm{mg} / \mathrm{kg}) ; \mathrm{C}_{\mathrm{f}}$ is the background trace element concentration $(\mathrm{mg} / \mathrm{kg}$ ). The background area is 'Background' Observatory (Institute of Atmospheric Optics, Siberian Branch of the Russian Academy of Sciences). If the snow is contaminated with more than one heavy metal, the contamination level is evaluated based on the total contamination factor $Z_{d}$, which is equal to:

$$
Z_{c}=\sum K_{k, i}-(n-1)
$$

$\mathrm{n}$ is the number of heavy metals, having $\mathrm{K}_{\mathrm{k}, \mathrm{i}} \geq 1.5$ [6-7].

Based on the $\mathrm{Z}_{\mathrm{c}}$ value, the degree (level) of snow contamination using the total contamination factor is as follows: $<32-$ allowable; 32-64 - moderately hazardous, 64-128 - hazardous; 128-256 - highly hazardous and > 256 - extremely hazardous [6-7].

Sanitary-hygienic assessment of the element content in solid air particles in the areas located close to boiler is performed by calculation of hazard quotient $\left(\mathrm{HQ}_{\mathrm{i}}\right)$ and non-carcinogenic human health risk assessment [13-14]. $\mathrm{HQ}_{\mathrm{i}}$ is calculated on the basis of data on the element composition of solid airborne particles deposited in snow.

Non-carcinogenic human health risk assessment from chronic inhalation of trace elements to the body is based on the hazard quotient $\left(\mathrm{HQ}_{\mathrm{i}}\right)$ calculations:

$$
H Q_{i}=C_{i a t m} / R_{f} C_{i}
$$

$\mathrm{R}_{\mathrm{f}} \mathrm{C}_{\mathrm{i}}$ is reference concentration of the $\mathrm{i}$-th element in the air, according to EPA's IRIS, HEAST EPA.

To identify priority organs and systems which are mostly affected by combined influence of several elements, total hazard index (HI) is calculated for each organ or system:

$$
H I=\sum H Q_{i}
$$

In cases when a metal affects the functioning of several systems or organs, its HQ was taken for each system separately.

Besides, the data on element air concentrations are used in calculations [10]. This data is reestablished taking into account air dust deposition rate of airborne dust and size of airborne dust particles.

\section{RESULTS AND DISCUSSION}

The analysis of concentration coefficients has shown that in the samples taken near the coal-fired boiler house there are $\mathrm{Sb}, \mathrm{Cd}, \mathrm{Sr}, \mathrm{Ba}$ and $\mathrm{Zn}$ that make a group of elements with high accumulation in terms of average values of concentration coefficients (Table 1). The cumulative pollution indicator amounts 47.8 on average, which corresponds to the environmental conditions of moderately hazardous contamination level and moderately hazardous for human health. The content of $\mathrm{Ni}, \mathrm{Sb}$ and $\mathrm{V}$ in samples of solid snow samples taken near the oil-fired boiler house is uneven. In terms of average values of concentration coefficients, $\mathrm{Ni}, \mathrm{Sb}$ and $\mathrm{V}$ form a group of elements with high accumulation in solid snow phase. Sr, Mo, $\mathrm{Cd}$ and $\mathrm{Ba}$ accumulate less intensively in the samples of solid snow phase, whereas the content of other elements ( $\mathrm{Cr}, \mathrm{Mn}, \mathrm{Co}, \mathrm{Cu}, \mathrm{Zn}, \mathrm{As}, \mathrm{Se}, \mathrm{W}, \mathrm{Pb}$ and $\mathrm{Hg}$ ) is close to the background values. 
Table 1 Geochemical characteristics of the solid phase of snow in the vicinity of coal-fired and oil-fired boiler houses in Tomsk Oblast

\begin{tabular}{|l|l|l|l|l|}
\hline \multirow{2}{*}{ Boiler house plant } & \multicolumn{2}{|c|}{ Coefficient concentration of trace elements } & \multirow{2}{*}{$\mathrm{Z}_{\mathrm{c}}$} \\
\cline { 2 - 5 } & $\geq 1.5$ & $1.6-5$ & $5-25$ & \\
\hline Coal-fired boiler house & $\mathrm{Se}_{0,1} \mathrm{As}_{0,3} \mathrm{~V}_{0,4} \mathrm{Cr}_{0,5} \mathrm{Cu}_{0,8}$ & $\mathrm{Hg}_{1,9} \mathrm{~Pb}_{2,4} \mathrm{Ba}_{3} \mathrm{Co}_{3,1}$ & $\mathrm{Cd}_{7,2} \mathrm{Sb}_{24,8}$ & 47.8 \\
& $\mathrm{~W}_{1,1} \mathrm{Mn}_{1,5}$ & $\mathrm{Ni}_{3,2} \mathrm{Mo}_{3,3} \mathrm{Sr}_{4,2}$ & & \\
\hline Oil-fired boiler house & $\mathrm{Se}_{0,1} \mathrm{~W}_{0,1} \mathrm{Cu}_{0,7} \mathrm{Cr}_{1,1} \mathrm{~Pb}_{1,4}$ & $\mathrm{Sr}_{2} \mathrm{Cd}_{2} \mathrm{Mo}_{2,2} \mathrm{Ba}_{2,2} \mathrm{~V}_{4,8}$ & $\mathrm{Sb}_{7,0} \mathrm{Ni}_{8,4}$ & 23.1 \\
& $\mathrm{As}_{1,4} \mathrm{Co}_{1,4} \mathrm{Hg}_{1,5} \mathrm{Mn}_{1,5} \mathrm{Zn}_{1,5}$ & & & \\
\hline
\end{tabular}

The most studied elements have calculated values of $\mathrm{HQ}_{\mathrm{i}}$ much less than 0.1 , which, according to the domestic and foreign recommendations [13-14], allows them to be considered as posing no risk to human health (Table 2).

Table 2 Non-carcinogenic human health risk assessment from chronic inhalation of trace elements to the body during inhalation in the vicinity of coal-fired and oil-fired boiler house plants in Tomsk Oblast

\begin{tabular}{|c|c|c|c|c|c|c|c|}
\hline \multirow{2}{*}{$\begin{array}{c}\text { Elem } \\
\text { ent }\end{array}$} & \multirow[t]{2}{*}{ Code CAS } & \multirow[t]{2}{*}{ Organs/systems } & \multirow{2}{*}{$\begin{array}{l}\mathrm{RFC}, \\
\mathrm{mkg} / \mathrm{m}^{3}\end{array}$} & \multicolumn{2}{|c|}{ Coal-fired boiler house } & \multicolumn{2}{|c|}{ Oil-fired boiler house } \\
\hline & & & & $\begin{array}{l}\mathrm{C}_{\mathrm{atm}} \pm \delta_{\mathrm{m}} \\
\mathrm{mkg} / \mathrm{m}^{3}\end{array}$ & $\begin{array}{l}\mathrm{HQ}_{\mathrm{i}} \pm \delta_{\mathrm{m}} \\
\text { units }\end{array}$ & $\begin{array}{l}\mathrm{C}_{\mathrm{atm}} \pm \delta_{\mathrm{m}} \\
\mathrm{mkg} / \mathrm{m}^{3}\end{array}$ & $\begin{array}{l}\mathrm{HQ}_{\mathrm{i}} \pm \delta_{\mathrm{m}} \\
\quad \text { units }\end{array}$ \\
\hline $\mathrm{Al}$ & $7429-90-5$ & $\begin{array}{l}\text { systema nervosum } \\
\text { centrale, respiration } \\
\text { organs }\end{array}$ & 5 & $3.85 \pm 1.99$ & $0.77 \pm 0.40$ & $0.39 \pm 0.07$ & $0.08 \pm 0.01$ \\
\hline $\mathrm{Mn}$ & $7439-96-5$ & $\begin{array}{c}\text { systema nervosum } \\
\text { centrale }\end{array}$ & 0.05 & $0.018 \pm 0.007$ & $0.37 \pm 0.15$ & $0.004 \pm 0.001$ & $0.07 \pm 0.02$ \\
\hline $\mathrm{Cu}$ & $7440-50-8$ & $\begin{array}{l}\text { respiration organs, } \\
\text { systematic effect }\end{array}$ & 0.02 & $0.005 \pm 0.002$ & $0.23 \pm 0.11$ & $8.5 \cdot 10^{-4} \pm 10^{-4}$ & $0.04 \pm 0.01$ \\
\hline $\mathrm{Ba}$ & $7440-39-3$ & reproductive function & 0.5 & $0.071 \pm 0.038$ & $0.14 \pm 0.08$ & $7 \cdot 10^{-3} \pm 10^{-3}$ & $0.014 \pm 0.003$ \\
\hline $\mathrm{Co}$ & $7440-48-4$ & $\begin{array}{l}\text { respiration organs, } \\
\text { systematic effect }\end{array}$ & 0.02 & $0.001 \pm 0,001$ & $0.07 \pm 0.04$ & $9.8 \cdot 10^{-5} \pm 10^{-5}$ & $0.005 \pm 0.001$ \\
\hline $\mathrm{Pb}$ & $7439-92-1$ & $\begin{array}{c}\text { systema nervosum } \\
\text { centrale, progression, } \\
\text { blood system }\end{array}$ & 0.15 & $0.0075 \pm 0.003$ & $0.05 \pm 0.01$ & $1.2 \cdot 10^{-3} \pm 10^{-4}$ & $0.008 \pm 0.001$ \\
\hline $\mathrm{Ni}$ & $7440-02-0$ & $\begin{array}{l}\text { respiration organs, } \\
\text { blood system, } \\
\text { immune system, } \\
\text { systema nervosum } \\
\text { centrale }\end{array}$ & 0.05 & $0.0003 \pm 0.0001$ & $0.005 \pm 0.002$ & $1.3 \cdot 10^{-3} \pm 10^{-4}$ & $0.03 \pm 0.003$ \\
\hline V & $7440-62-2$ & respiration organs & 0.07 & $0.0006 \pm 0.0003$ & $0.009 \pm 0.004$ & $1.2 \cdot 10^{-3} \pm 10^{-4}$ & $0.017 \pm 0.002$ \\
\hline
\end{tabular}

$\mathrm{C}_{\mathrm{atm}}\left(\mathrm{mkg} / \mathrm{m}^{3}\right)$ is the reestablished element concentration in air using the data on element composition of solid snow sediments; $\mathrm{HQ}_{\mathrm{i}}$ is the hazard quotient of non-carcinogenic human health risk assessment from chronic inhalation of trace elements to the body.

Hazard quotient of six elements is higher than $0.05 ; \mathrm{Al}, \mathrm{Mn}, \mathrm{Cu}, \mathrm{Ba}, \mathrm{Co}$ and $\mathrm{Pb}$ constitute the maximum specific share in the integral level of non-carcinogenic risk from chronic inhalation of metals in the vicinity of coal-fired boiler house, whereas in the vicinity of oil-fired boiler house are $\mathrm{Al}, \mathrm{Mn}, \mathrm{Cu}, \mathrm{Ni}$ and $\mathrm{V}$.

\section{CONCLUSION}

It is revealed that the potential element-indicators in solid snow phase posing a serious environmental risk in the vicinity of coal-fired boiler house are $\mathrm{Cd}, \mathrm{Sb}, \mathrm{Pb}, \mathrm{Mo}, \mathrm{Sr}, \mathrm{Ba}, \mathrm{Ni}, \mathrm{Mo}, \mathrm{Zn}$ and $\mathrm{Co}$; in the vicinity of oil-fired boiler house are $\mathrm{V}$, $\mathrm{Ni}$ and $\mathrm{Sb}$. It is stated that near the coal-fired boiler house there is the moderately hazardous level of contamination, while in vicinity of the oil-fired boiler house there is the allowable level of contamination. The study has shown that in 
vicinity of the coal-fired boiler house there are more hazardous ecological conditions as compared to the environment near the oil-fired boiler house. The revealed elements-indicators in the solid snow phase are most likely to reflect the specificity of fuel and fly ash. When burning, they are released and changed into more available forms digested by human beings and biota.

\section{ACKNOWLEDGMENTS}

This research was funded by Russian Foundation for Basic Research (16-45-700184p_a). The experimental procedure are carried out at Tomsk Polytechnic University within the framework of Tomsk Polytechnic University Competitiveness Enhancement Program grant.

\section{REFERENCES}

[1] Pope III, A.C., Dockery, D.W. "Health Effects of Fine Particulate Air Pollution: Lines that Connect," J Air Waste Manage 56 (6), 709-742 (2006).

[2] Belan, B.D., Rasskazchikova, T.M., Simonenkov, D.V., Tolmachev, G.N., Fofonov, A.V. "Chemical composition of atmospheric aerosols over background areas of the southern part of Western Siberia observed during the IAO Complex Atmospheric Radiation Experiment carried out in December 2015," Proc. SPIE 10035, 1003549 (2016).

[3] Belan, B.D., Kozlov, A.V., Simonenkov, D.V., Tolmachev, G.N., Tsaruk, V.V. "Aerosol number size distributions in the lower troposphere over a background region and megalopolis (Novosibirsk) on result of airborne sounding in 20112013," Proc. SPIE 9292, 929244 (2014).

[4] Sharma, R., Pervez, Y., Pervez, S. "Seasonal evaluation and spatial variability of suspended particulate matter in the vicinity of a large coal-fired power station in India - A case study," Environ Monit Assess 102, 1-13 (2005).

[5] Samet, J., Rappold, A., Graff, D., et al. "Concentrated ambient ultrafine particle exposure induces cardiac changes in young healthy volunteers," Am J Respir Crit Care Med. 179, 1034-42 (2009).

[6] Saet, Yu.E., Revic, B.A., Janin, E.P., Smirnova, R.S. [Environmental geochemistry], Nedra, Moscow, p 335 (1990).

[7] Baltrenaite, E., Baltrenas, P., Lietuvninkas, A., Sereviciene, V., Zuokaite, E. "Integrated evaluation of aerogenic pollution by air-transported heavy metals $(\mathrm{Pb}, \mathrm{Cd}, \mathrm{Ni}, \mathrm{Zn}, \mathrm{Mn}$ and $\mathrm{Cu})$ in the analysis of the main deposit media," Environ Sci Pollut Res 21 (1), 299-313 (2014).

[8] Raputa, V.F., Yaroslavtseva, T.V. "Investigation of snow cover dust pollution by contact and satellite observations," Proc. SPIE 9680, 968064 (2015).

[9] Ianchenko, N.I., Kondratiev, V.V., Verkhoturov, V.V. "Features of the elemental composition of snow cover in the area of production primary aluminum emissions," Proc. SPIE 10035, 1003563 (2016).

[10] Osipova, N.A., Filimonenko, K.A., Talovskaya, A.V., Yazikov, E.G. "Geochemical Approach to Human Health Risk Assessment of Inhaled Trace Elements in the vicinity of Industrial Enterprises in Tomsk, Russia," Hum Ecol Risk Assess 21 (6), 1664-1685 (2015).

[11] Talovskaya, A.V., Filimonenko, E.A., Osipova, N.A., Lyapina, E.E., Yazikov, E.G. "Toxic elements (As, Se, Cd, $\mathrm{Hg}, \mathrm{Pb}$ ) and their mineral and technogenic formations in the snow cover in the vicinity of the industrial enterprises of Tomsk," IOP C. Ser. Earth. Env. 21, 012042 (2014).

[12] Talovskaya, A.V., Yazikov, E.G., Filimonenko, E.A., Samokhina, N.P., Shakhova, T.S., Parygina, I.A. "Element composition of solid airborne particles deposited in snow in the vicinity of gas-fired heating plant," Proc. SPIE 10035, 100354 (2016).

[13] Manual for human health risk assessment of chemical substances impact. P. 2.1.10.1920-04, Federal Center Gossanipednadzor, Moscow, p 273 (2004).

[14] USEPA (US Environmental Protection Agency). Risk Assessment Guidance for Superfund. Human Health Evaluation Manual. 1 Part A. Interim Final. Office of Solid Waste and Emergency Respons., Washington, DC USA (1989). 